\title{
Blossoming Characteristics in Black Cumin Genotypes in Relation Seed Yield Influenced by Sowing Time
}

\author{
Md Ziaul Haq1*, M. Mofazzal Hossain², M. Moynul Haque1, Mira Rani Das³, \\ Muhammad Shamsul Huda 4 \\ ${ }^{1}$ Seed Science and Technology Unit, Bangabandhu Sheikh Mujibur Rahman Agricultural University, Gazipur, \\ Bangladesh \\ ${ }^{2}$ Department of Horticulture, Bangabandhu Sheikh Mujibur Rahman Agricultural University, Gazipur, Bangladesh \\ ${ }^{3}$ Agriculture Training Institute, Gazipur, Bangladesh \\ ${ }^{4}$ Scientific Officer, Farm Division, Bangladesh Agricultural Research Institute Joydebpur, Gazipur, Bangladesh \\ Email: ${ }^{\text {ziaul33@yahoo.com }}$
}

Received 11 April 2015; accepted 16 May 2015; published 20 May 2015

Copyright (C) 2015 by authors and Scientific Research Publishing Inc.

This work is licensed under the Creative Commons Attribution International License (CC BY).

http://creativecommons.org/licenses/by/4.0/

(c) (i) Open Access

\begin{abstract}
Black cumin (Nigella sativa L.; Family-Ranunculaceae) is an important spice crop. Mature seeds are consumed for edible and medical purposes and also used as a food additive and flavour. Seed of black cumin has great potentiality as spice crop due to nutritive and medicinal values. The experiments were carried out at Bangabandhu Sheikh Mujibur Rahman Agricultural University, Gazipur during 2011 to 2012 to determine optimum planting time for seed production of black cumin. The experiment was two factorials. Factor $A: 4$ genotypes were $V_{1}$ : Exotic, Iran; $V_{2}$ : BARI kalozira-1; $V_{3}$ : Local, Faridpur and $V_{4}$ : Local, Natore. Factor B: sowing date: $D_{1}: 16$ October; $D_{2}$ : 1 November; $D_{3}: 16$ November and $D_{4}: 1$ December. Therefore, treatment combinations were 16 in total. So, in 3 replications total plot was 48 . Result revealed that significantly the highest $2.37 \mathrm{t} / \mathrm{ha}$ in $V_{1}$, followed by $V_{2}(1.96 \mathrm{t} / \mathrm{ha}) . \mathrm{V}_{2}$ and $V_{3}(1.97 \mathrm{t} / \mathrm{ha})$ were statistically similar and maximum yield was obtained from $D_{2}(2.65 \mathrm{t} / \mathrm{ha})$. In combined effect, maximum yield $3.00 \mathrm{t} / \mathrm{ha}$ was obtained in $V_{1} D_{2 .}$. Investigation on time of sowing revealed that performance of black cumin was better in earlier sowings (16 October, 1 November) than later ones. The highest yield (4g plant ${ }^{-1} ; 2.65$ tha $^{-1}$ ) was obtained when the crop was sown on 1 November. Among the genotypes, the exotic one with sowing in 1 November gave the highest seed yield (4.54 g/plant ${ }^{-1} ; 3.00$ t$\left.^{-h} \mathrm{a}^{-1}\right)$.
\end{abstract}

\section{Keywords}

Black Cumin, Flower Blooming, Capsule, Seed Yield, Sowing Time

\footnotetext{
${ }^{*}$ Corresponding author.
}

How to cite this paper: Haq, M.Z., Hossain, M.M., Haque, M.M., Das, M.R. and Huda, M.S. (2015) Blossoming Characteristics in Black Cumin Genotypes in Relation Seed Yield Influenced by Sowing Time. American Journal of Plant Sciences, 6, 1167-1183. http://dx.doi.org/10.4236/ajps.2015.68121 


\section{Introduction}

Black cumin (Nigella sativa L.; Family-Ranunculaceae) is an important annual herbaceous plant. Spice crop is cultivated in widely cultivated throughout South Europe, Syria, Egypt, Saudi Arabia, Iran, Pakistan, India and Turkey [1]-[3]. For successful production of any crop, appropriate planting time is very important. Especially for seed production, sowing time is very sensitive for quality seed production. Planting controls the phonological development which influences seed production [4]. Shortening of the growing cycle decreases the amount of radiation intercepted during the growing season and thus total dry weight of plant [5] [6]. With delayed sowing, development is accelerated because the crops encounter higher temperatures during the vegetative growth [7] and decreases seed weight and the number of umbrella per plant [4] [8]. Because of occurrence lack of suddenly winter chilling, delayed sowing date is better [8] [9]. Early sowing has been favorable for disease, and leads to early flowering, resulting poor quality of seed [4]. Optimum temperature for germination is $16.19^{\circ} \mathrm{C}$ to $22.14^{\circ} \mathrm{C}$ [10], so black cumin is plenty during winter season in Bangladesh. To realize the full yield potential characteristics of black cumin, agricultural practices will have to be optimized for its production. Optimum sowing time of black cumin in Bangladesh has rarely investigated. This study aims 1) to assess the effect of various sowing time on flowering for seed production of black cumin genotypes, and 2) to determine the interaction effect of sowing time and genotypes.

\section{Materials and Methods}

The study was conducted at the Horticulture Research Field, Bangabandhu Sheikh Mujibur Rahman Agricultural University, Gazipur during the winter season of 2011-12. The experiment having two factors was laid out in a randomized complete block design with three replications. The treatments were randomly allotted in each block. Each block consisted of 16 plots and the dimension of each plot was $1.2 \mathrm{~m} \times 1.2 \mathrm{~m}\left(1.44 \mathrm{~m}^{2}\right)$ having a plot to plot and block to block distances of $0.5 \mathrm{~m}$ and $1.0 \mathrm{~m}$, respectively. Soil of the experimental field was silty clay loam and soil $\mathrm{P}^{\mathrm{H}} 5,84$. The experiment plots were manured and fertilized with Cowdung, Urea, TSP and MP at the rate of $10 \mathrm{t}, 125,95$ and $75 \mathrm{~kg} /$ ha respectively [11]. The seeds were mixed with some loose soil to allow uniform sowing in rows. Then, seeds were sown in rows $15 \mathrm{~cm}$ apart continuously by hand @ $10 \mathrm{~kg} / \mathrm{ha}$ [11], maintaining a depth of one cm. Continuous line sowing was done to maintain plant to plant distance $10 \mathrm{~cm}$ by thinning later on [11]. The seeds were covered with loose soil properly just after sowing and gently pressed by hands. The crop was harvested when $50 \%$ of the capsules changed color from green to straw color.The experiment was two factorials. Factor A: 4 genotypes were $\mathrm{V}_{1}$ : Exotic, Iran; $\mathrm{V}_{2}$ : BARI kalozira-1; $\mathrm{V}_{3}$ : Local, Faridpur and $\mathrm{V}_{4}$ : Local, Natore. Factor $\mathrm{B}$ : Sowing date: $\mathrm{D}_{1}$ : 16 October; $\mathrm{D}_{2}: 1$ November; $\mathrm{D}_{3}$ : 16 November and $\mathrm{D}_{4}: 1$ December. Therefore, treatment combinations were 16 in total. So, in 3 replications total plot was 48 . Data were collected from the inner rows of each plot to avoid the border effect. In each unit plot, 10 plants were selected randomly for recording data. The following seed yield and yield contributing characters were recorded. Days to $\mathbf{1}^{\text {st }}$ emergence: Number of days required for first emergence after seed sowing was calculated from all the plots separately by close observation after seed sowing. Days to $\mathbf{5 0 \%}$ emergence: Number of days required for $50 \%$ emergence after seed sowing was calculated from all the plots separately by close observation after seed sowing. Days to $1^{\text {st }}$ flower bud initiation: Days to $1^{\text {st }}$ flower bud initiation was recorded by calculating the days from the date of sowing to bud initiation by observing the plants every morning. Days to flower bud initiation in $\mathbf{5 0 \%}$ plants: Days to 50\% flower bud initiation was recorded by calculating the days from the date of sowing to bud initiation by observing the plants every morning. Days to $1^{\text {st }}$ flower blooming: Days to $1^{\text {st }}$ flower blooming was recorded by calculating the days from the date of sowing to bud initiation by observing the plants every morning (1st opened flower in plot). Days to flower blooming in $\mathbf{5 0 \%}$ plants: Days to flower in 50\% plant was recorded by counting the days from the date of sowing to flower in 50\% plants every morning (50\% of the plant in a plot opened flower).Days to $1^{\text {st }}$ capsule setting: Days to $1^{\text {st }}$ capsule setting was recorded by counting the days from the date of sowing every morning. Days to capsule setting in $\mathbf{5 0 \%}$ plants: Days to capsule setting in $50 \%$ plants was recorded by counting the days from the date of sowing every morning. Days to first capsule ripening: Days to $1^{\text {st }}$ capsule ripening in each plot was recorded by counting the days from the date of sowing every morning. When capsule colour was changed from green to straw, then it was counted as ripened. Days to capsule ripening in $\mathbf{5 0 \%}$ plants: Days to capsule ripening in $50 \%$ plants in each plot was recorded by counting the days from the date of sowing every morning. When capsule colour was changed from green to straw, then it was counted as ripened. This parameter indicates whether the genotypes was short-durated or late. The collected data 
were analyzed statistically using MSTAT-C computer package (Michigan State University, East Lansing, MI, USA) following the methods of [12]. The analysis of variance procedure (ANOVA), differences among treatment means were determined using the Least Significant Difference (LSD) at 5\% level of significance

\section{Results and Discussion}

\subsection{Results}

The present investigation initiated to study the effect of planting time on the blossoming characters in black cumin genotypes. The results obtained are presented in tables and figures and discussed character wise under the following heads:

\subsection{Days to $1^{\text {st }}$ Emergence}

Variation among the genotypes was observed and the days to $1^{\text {st }}$ emergence ranged from 7.42 to 8.58 days (Table 1). The $V_{3}$ genotype took the highest days (8.58 days) to $1^{\text {st }}$ emergence, which had no significance difference with genotype $V_{2}$ (8.50 days) and $V_{4}$ (8.42 days). The earliest emergence was recorded in the $V_{1}$ genotype (7.42 days), which was statistically different to all. $\mathrm{D}_{1}$ and $\mathrm{D}_{2}$ took 7.67 and 7.83 days which was statistically similar. $\mathrm{D}_{3}$ (8.75 days) and $\mathrm{D}_{4}$ (8.67 days) were also statistically similar. In combined effect, statistically higher days were obtained from $V_{2}, V_{3}$ and $V_{4}$ with $D_{3}$ and $D_{4}$ which was 9 days. The lowest days 7 were showed from $\mathrm{V}_{1} \mathrm{D}_{1}$ and $\mathrm{V}_{1} \mathrm{D}_{2}$.

\subsection{Days to $50 \%$ Emergence}

Evident of significant different days required for $50 \%$ emergence were observed in main effect of genotypes, ranging from 9.83 days $\left(\mathrm{V}_{1}\right)$ to 11.83 days $\left(\mathrm{V}_{4}\right)$ (Table 1$)$. $\mathrm{V}_{3}$ (11.75 days) was statistically similar to $\mathrm{V}_{4} \cdot \mathrm{V}_{2}$ (10.75 days) showed moderate required days. Requiring the lowest days showed higher vigor of $V_{1}$. Variation also observed in date of planting. $\mathrm{D}_{1}$ and $\mathrm{D}_{2}$ each took 10.25 days, $\mathrm{D}_{3}$ and $\mathrm{D}_{4}$ each took 11.83 days. In combined effect, statistically higher 12.67 days required for $\mathrm{V}_{3} \mathrm{D}_{4}, \mathrm{~V}_{4} \mathrm{D}_{3}$ and $\mathrm{V}_{4} \mathrm{D}_{4}$. The lowest 9 days was observed in $V_{1} D_{1}$ and $V_{2} D_{2}$. In interaction days to $50 \%$ emergence ranged from 9.00 to 12.67 days. Lowest days required was observed in $V_{1} S_{2}$. All combination of spacing with $V_{3}$ and $V_{4}$ showed statistically similar as well as highest days required.

\subsubsection{Days to $1^{\text {st }}$ Flower Bud Initiation}

There was clear significant different among genotypes in $1^{\text {st }}$ flower bud initiation (Table 1). It was the highest (51.83 days) in $\mathrm{V}_{1}$, followed by $\mathrm{V}_{3}$ (49.08 days). $\mathrm{V}_{2}$ (47.92 days) and $\mathrm{V}_{4}$ (45.42 days) were significantly different from each other. It may be controlled genetically. In case of sowing date, early sowing took higher as well as late sowing took lower time. $\mathrm{D}_{1}, \mathrm{D}_{2}, \mathrm{D}_{3}$ and $\mathrm{D}_{4}$ took 56.92, 47.42, 46.08 and 43.83 days simultaneously, which each was significantly different from each other. In interaction, $\mathrm{V}_{3} \mathrm{D}_{1}$ took the highest days (59.00 days) to $1^{\text {st }}$ flower bud initiation, where the lowest 39.33 days was obtained from $\mathrm{V}_{4} \mathrm{D}_{4}$.

\subsubsection{Days to Flower Bud Initiation in 50\% Plants}

Days to $50 \%$ flower bud initiation significantly varied among genotypes (Table 1). It was the highest in $\mathrm{V}_{1}$ (60.00 days) and the lowest 54.67 days in $\mathrm{V}_{2}$. $\mathrm{V}_{2}$ was statistically similar to $\mathrm{V}_{4}$ (54.92 days). $\mathrm{V}_{3}$ (56.00 days) required statistically moderate days. On the other hand, early sowing $\mathrm{D}_{1}$ took the highest (65.58 days) and late sowing $\mathrm{D}_{4}$ took the lowest (50.75 days). $\mathrm{D}_{2}$ and $\mathrm{D}_{3}$ took 56.42 and 52.83 days. Each date was statistically different from each other. In interaction, $\mathrm{V}_{1} \mathrm{D}_{1}$ needed the highest (66.33 days) and $\mathrm{V}_{4} \mathrm{D}_{4}$ needed the lowest (48.33 days).

\subsubsection{Days to $1^{\text {st }}$ Flower Blooming}

Significant variation was observed in $V_{1}$ with other genotype in days to $1^{\text {st }}$ flower blooming (Table 1$)$. $V_{1}$ took maximum days ( 61.75 days) which was statistically different from $\mathrm{V}_{2}$ (60.33 days), $\mathrm{V}_{3}$ (59.75 days) and $\mathrm{V}_{4}$ (59.33 days). $V_{2}, V_{3}$ and $V_{4}$ were statistically similar. A clear different was found in various date of sowing. Maximum (70.67 days) was observed in $\mathrm{D}_{1}$, where minimum (53.17 days) from $\mathrm{D}_{4} \cdot \mathrm{D}_{2}\left(61.17\right.$ days) and $\mathrm{D}_{3}$ (56.17 days) showed moderate time. Each sowing date was significantly different from each other. In interaction between genotypes and date of sowing, $\mathrm{V}_{4} \mathrm{D}_{1}$ took the highest (71.33 days) and $\mathrm{V}_{4} \mathrm{D}_{4}$ (51.67 days) took the lowest time for $1^{\text {st }}$ flower blooming. 
Table 1. Days to emergence and flowering characteristics in black cumin genotypes as influenced by sowing time.

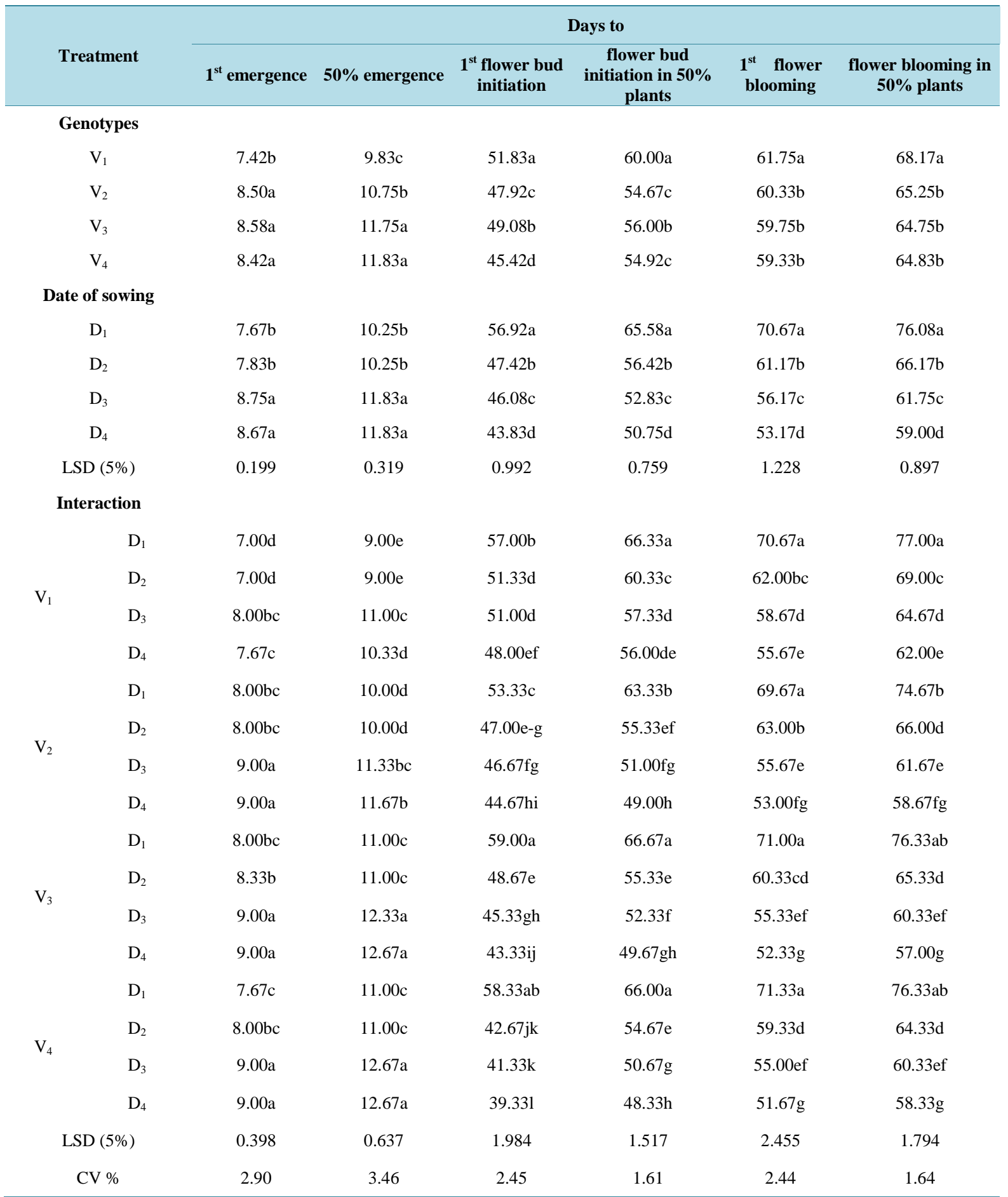

Means followed by the same letter(s) in a column are not significantly different. Variety: Exotic $\left(\mathrm{V}_{1}\right)$; BARI kalozira-1 ( $\left.\mathrm{V}_{2}\right)$; Faridpur local ( $\left.\mathrm{V}_{3}\right)$; Natore local $\left(\mathrm{V}_{4}\right)$. Date of sowing: 16 Oct, 2011( $\left.\mathrm{D}_{1}\right)$; 1Nov, $2011\left(\mathrm{D}_{2}\right) ; 16 \mathrm{Nov}, 2011\left(\mathrm{D}_{3}\right) ; 1$ Dec, $2011\left(\mathrm{D}_{4}\right)$.

\subsubsection{Days to Flower Blooming in 50\% Plants}

There was significant variation in $V_{1}$ with other genotype in days to $50 \%$ flower blooming (Table 1 ). $V_{1}$ take maximum days (68.17 days) which were statistically different from $\mathrm{V}_{2}$ (65.25 days), $\mathrm{V}_{3}$ (64.75 days) and $\mathrm{V}_{4}$ (64.83 days). $\mathrm{V}_{2}, \mathrm{~V}_{3}$ and $\mathrm{V}_{4}$ were statistically similar. A clear different was found in various date of sowing. 
Maximum (76.08) days was observed in $\mathrm{D}_{1}$, where minimum (59.00 days) from $\mathrm{D}_{4} \cdot \mathrm{D}_{2}\left(61.17\right.$ days) and $\mathrm{D}_{3}$ (61.75 days) showed moderate time. Each sowing date was significantly different. In interaction between genotypes and date of sowing, $\mathrm{V}_{1} \mathrm{D}_{1}$ took the highest (77.00 days) and $\mathrm{V}_{4} \mathrm{D}_{4}$ (58.33 days) took the lowest time for $50 \%$ flower blooming.

\subsubsection{Days to $1^{\text {st }}$ Capsule Setting}

Variation in days to $1^{\text {st }}$ capsule setting was observed in genotypes (Table 2). $\mathrm{V}_{1}$ obtained 81.83 days which was maximum and statistically different from other genotype, where $\mathrm{V}_{2}$ took 75.08 days which was minimum. $\mathrm{V}_{3}$ take 78.83 days followed by $\mathrm{V}_{4}$ (76.42 days). Each genotype was statistically different. On the other hand, sowing date $\mathrm{D}_{1}$ obtained 87.42 days to $1^{\text {st }}$ capsule setting, followed by $\mathrm{D}_{2} 78.83$ days. $\mathrm{D}_{3}$ took 74.33 days which was statistically different from the minimum days (71.58) obtained by $\mathrm{D}_{4}$. In interaction, $\mathrm{V}_{1} \mathrm{D}_{1}$ showed 90.33 days

Table 2. Days to fruiting and maturation characteristics in black cumin genotypes as influenced by sowing time.

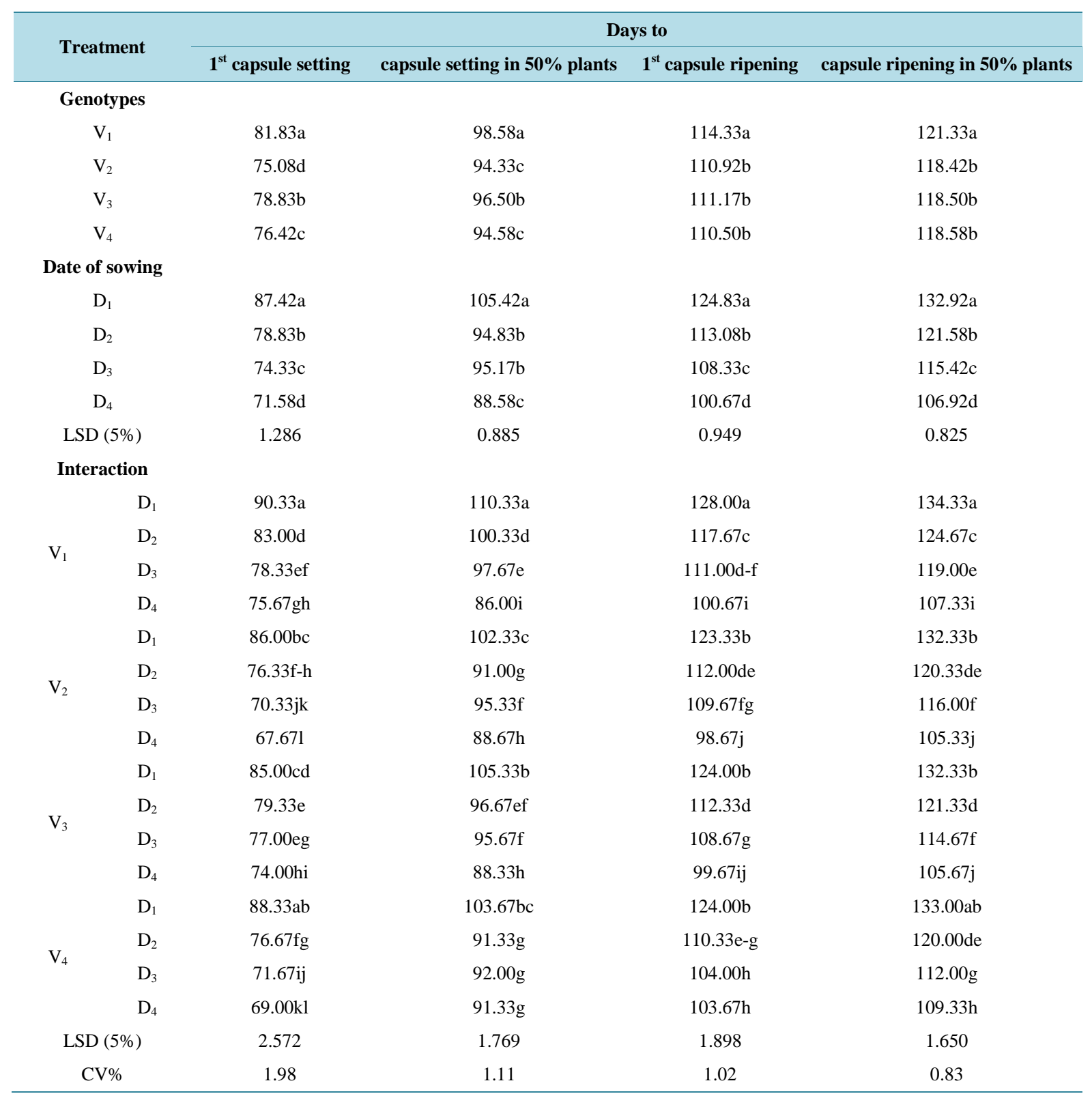

Means followed by the same letter(s) in a column are not significantly different. Variety: Exotic $\left(\mathrm{V}_{1}\right)$; BARI kalozira-1 ( $\left.\mathrm{V}_{2}\right)$; Faridpur local ( $\left.\mathrm{V}_{3}\right)$; Natore local $\left(\mathrm{V}_{4}\right)$. Date of sowing: 16 Oct, 2011( $\left.\mathrm{D}_{1}\right) ; 1$ Nov, $2011\left(\mathrm{D}_{2}\right) ; 16 \mathrm{Nov}, 2011\left(\mathrm{D}_{3}\right) ; 1$ Dec, 2011( $\left.\mathrm{D}_{4}\right)$. 
which was maximum, where $\mathrm{V}_{2} \mathrm{D}_{4}$ took minimum (67.67 days).

\subsubsection{Days to Capsule Setting in 50\% Plants}

Days to $50 \%$ capsule setting was statistically varied in genotypes (Table 2) ranging from 94.58 days $\left(\mathrm{V}_{4}\right)$ to 98.58 days $\left(\mathrm{V}_{1}\right) . \mathrm{V}_{2}$ (94.33 days) was statistically different from $\mathrm{V}_{1}$ and $\mathrm{V}_{3}$ (96.50 days), but similar with $\mathrm{V}_{4}$. Days to $50 \%$ capsule setting clearly distinguished by spacing. It increased with increasing spacing, ranged from 88.58 days $\left(\mathrm{D}_{4}\right)$ to 105.42 days $\left(\mathrm{D}_{1}\right)$. $\mathrm{D}_{3}$ showed 94.83 days and $\mathrm{D}_{3} 95.17$ days, which each was statistically similar. In combination effect, it ranged from 86.00 days $\left(\mathrm{V}_{1} \mathrm{D}_{1}\right)$ to 110.33 days $\left(\mathrm{V}_{1} \mathrm{D}_{1}\right)$. Gradually less time required from $\mathrm{D}_{1}$ to $\mathrm{D}_{4}$ with interaction with all genotypes.

\subsubsection{Days to $1^{\text {st }}$ Capsule Ripening}

In days to first capsule ripening, $V_{1}$ (114.33 days) was statistically different from $V_{2}$ (110.92 days), $V_{3}$ (111.17 days) and $\mathrm{V}_{4}$ (110.50 days). $\mathrm{V}_{2}, \mathrm{~V}_{3}$ and $\mathrm{V}_{4}$ were statistically similar (Table 2). In date of sowing, the highest days (124.83 days) were obtained by $D_{1}$, as well as lowest (100.67 days) by $\mathrm{D}_{4} . \mathrm{D}_{2}$ and $\mathrm{D}_{3}$ take 113.08 and 108.33 days simultaneously. Each date was significantly different. In combined effect, $\mathrm{V}_{1} \mathrm{D}_{1}$ took maximum time (128.00 days), where minimum (103.67 days) obtained from $\mathrm{V}_{4} \mathrm{D}_{4}$.

\subsubsection{Days to Capsule Ripening in 50\% Plants}

There was significant different in days to first capsule ripening (Table 2). $V_{1}$ (121.33 days) was statistically different from $\mathrm{V}_{2}$ (118.42 days), $\mathrm{V}_{3}$ (118.50 days) and $\mathrm{V}_{4}$ (118.58 days). $\mathrm{V}_{2}, \mathrm{~V}_{3}$ and $\mathrm{V}_{4}$ were statistically similar. In date of sowing, highest days (132.92) were obtained by $\mathrm{D}_{1}$, as well as the lowest (106.92 days) by $\mathrm{D}_{4} \cdot \mathrm{D}_{2}$ and $\mathrm{D}_{3}$ take 121.58 and 115.42 days simultaneously. Each date was significantly different. In combined effect, $\mathrm{V}_{1} \mathrm{D}_{1}$ took maximum time (134.33 days), where minimum (109.33 days) obtained from $\mathrm{V}_{4} \mathrm{D}_{4}$. The finding was nearly supported by BARI (2007) describing 135 to 145 days for ripening.

\subsubsection{Plant Height (cm)}

Genotypes were significantly different in plant height (Table 3). Maximum height $51.83 \mathrm{~cm}$ was obtained from $\mathrm{V}_{1}$ and minimum $44.13 \mathrm{~cm}$ from $\mathrm{V}_{4} \cdot \mathrm{V}_{2}(46.81 \mathrm{~cm})$ and $\mathrm{V}_{3}(46.46 \mathrm{~cm})$ was statistically similar. Date of sowing was also significantly different from each other. Maximum height was found in $\mathrm{D}_{2}(50.78 \mathrm{~cm})$, and minimum $(44.15 \mathrm{~cm})$ from $\mathrm{D}_{4}$. $\mathrm{D}_{1}$ and $\mathrm{D}_{3}$ showed 48.31 and $45.98 \mathrm{~cm}$ simultaneously. In combined effect of genotype and date of sowing, $\mathrm{V}_{1} \mathrm{D}_{2}$ showed $55.83 \mathrm{~cm}$ which was maximum, and minimum $(41.20 \mathrm{~cm})$ from interaction of $\mathrm{V}_{4}$ and $\mathrm{D}_{4}$.

\subsubsection{Number of Primary Branches per Plant}

Primary branches per plant are an important yield contributing character (Table 3). It was the highest 4.73 in $\mathrm{V}_{4}$, which was statistically similar to $V_{1}$ (4.63). Also $V_{1}$ and $V_{2}$ (4.53) was statistically similar. Significantly the lowest primary branch 4.30 was obtained from $\mathrm{V}_{3}$. In case of $\mathrm{V}_{2}$, date of sowing was statistically different from each other. $\mathrm{D}_{1}$ (4.81) and $\mathrm{D}_{2}$ (4.82) was statistically similar, followed by $\mathrm{D}_{3}(4.35)$. $\mathrm{D}_{4}$ obtained 4.20 which were the lowest among dates. In interaction number of primary branch 5.00 was the highest in $\mathrm{V}_{1} \mathrm{D}_{1}$, as well as the lowest (4.00) in $\mathrm{V}_{3} \mathrm{D}_{4}$.

\subsubsection{Number of Secondary Branches per Plant}

It was the highest in $V_{1}$ (8.89), followed by $V_{2}$ (8.68) (Table 3). $V_{4}$ obtained 8.07 which was statistically different from $V_{3}$ (7.83), the lowest number of secondary branch. In case of date of sowing, $D_{1}(9.68)$ and $D_{2}(9.81)$ was statistically similar, followed by $\mathrm{D}_{3}$ (7.27). $\mathrm{D}_{4}$ obtained the lowest number of secondary branch (6.70) which was statistically different from $D_{3}$. In interaction, $V_{1} D_{2}$ (10.73) gave the highest number of secondary branch, and $\mathrm{V}_{3} \mathrm{D}_{4}(6.10)$ showed the lowest.

\subsubsection{Number of Tertiary Branches per Plant}

The number of tertiary branch was the highest in $V_{1}$ (20.23), followed by $V_{2}$ (17.48) (Table 3). $V_{4}$ obtained 16.43 which were statistically different from the lowest number of tertiary branch (15.62) which obtained from $V_{3}$. In case of date of sowing, $D_{1}(19.46)$ and $D_{2}$ (19.82) was statistically different, followed by $D_{3}(15.78)$. $D_{4}$ obtained the lowest number of tertiary branch (14.69) which was statistically different from $\mathrm{D}_{3}$. In interaction, 
Table 3. Plant height and branching characteristics in black cumin genotypes as influenced by sowing time.

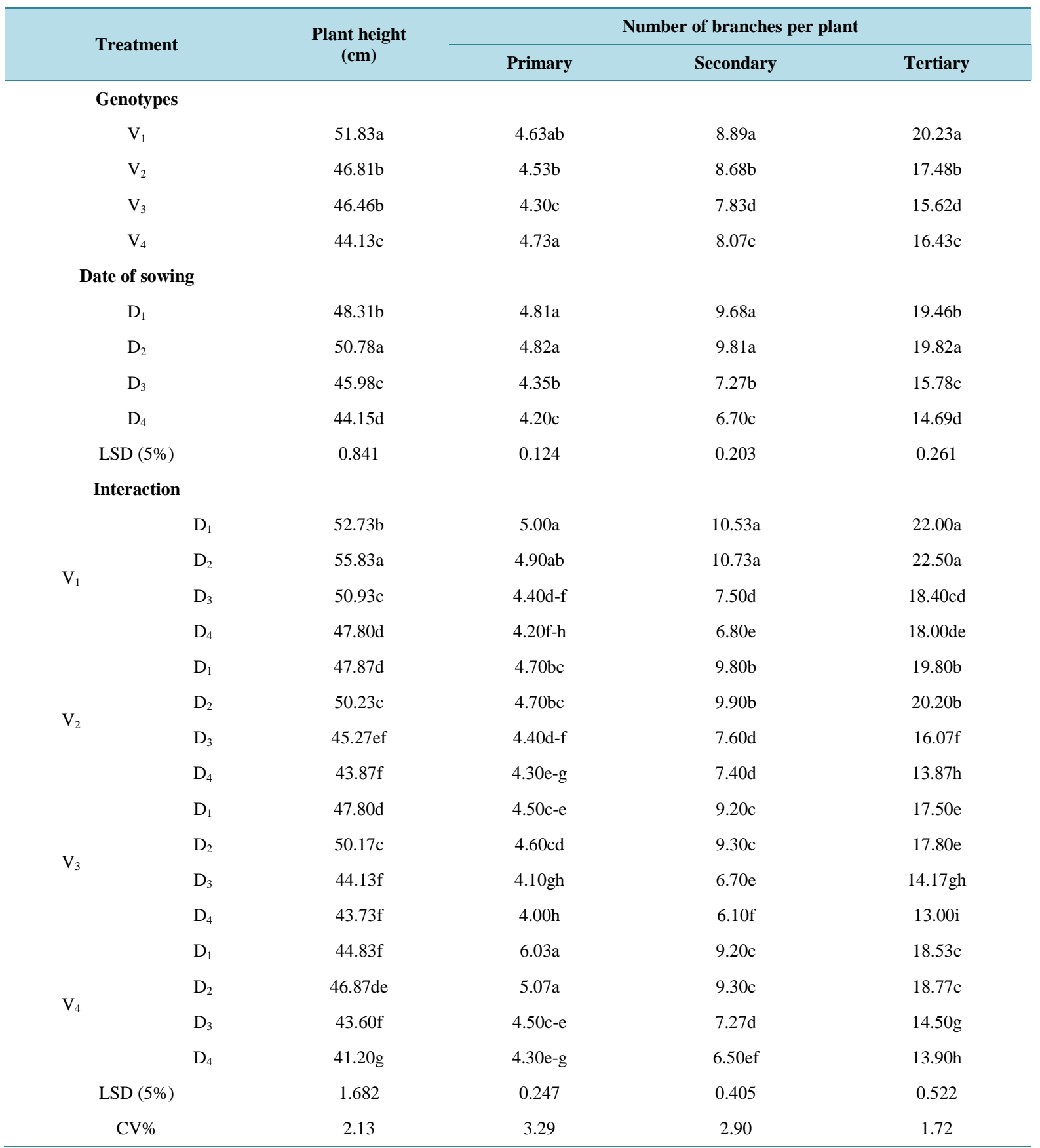

Means followed by the same letter(s) in a column are not significantly different. Variety: Exotic $\left(\mathrm{V}_{1}\right)$; BARI kalozira-1 $\left(\mathrm{V}_{2}\right)$; Faridpur local $\left(\mathrm{V}_{3}\right)$; Natore local $\left(\mathrm{V}_{4}\right)$. Date of sowing: 16 Oct, 2011(D $\left.\mathrm{D}_{1}\right) ; 1$ Nov, $2011\left(\mathrm{D}_{2}\right) ; 16$ Nov, $2011\left(\mathrm{D}_{3}\right) ; 1$ Dec, 2011( $\left.\mathrm{D}_{4}\right)$.

$V_{1} D_{2}$ (22.00) gave the highest number of tertiary branch, and $V_{3} D_{4}(13.00)$ showed the lowest.

\subsubsection{Length of Leaf $(\mathrm{cm})$}

There was no significant different among genotypes in leaf, ranged from $3.03 \mathrm{~cm}\left(\mathrm{~V}_{4}\right)$ to $3.05 \mathrm{~cm}\left(\mathrm{~V}_{1}\right)$ (Table 4). $\mathrm{V}_{2}$ and $\mathrm{V}_{3}$ showed 3.04 and $3.06 \mathrm{~cm}$ simultaneously. In case of date of sowing, it was the highest in $\mathrm{D}_{2}(3.27 \mathrm{~cm})$ which was statistically similar to $\mathrm{D}_{1}(3.23 \mathrm{~cm})$, followed by $\mathrm{D}_{3}(2.93 \mathrm{~cm})$. $\mathrm{D}_{4}$ showed the statistically the lowest leaf length $(2.75 \mathrm{~cm})$. In interaction, it was the highest $(3.27 \mathrm{~cm})$ in $\mathrm{V}_{1} \mathrm{D}_{2}$ and the lowest $(2.67 \mathrm{~cm})$ in $\mathrm{V}_{4} \mathrm{D}_{4}$. 
Table 4. Leaf, capsule and pedicle characteristics in black cumin genotypes as influenced by sowing time.

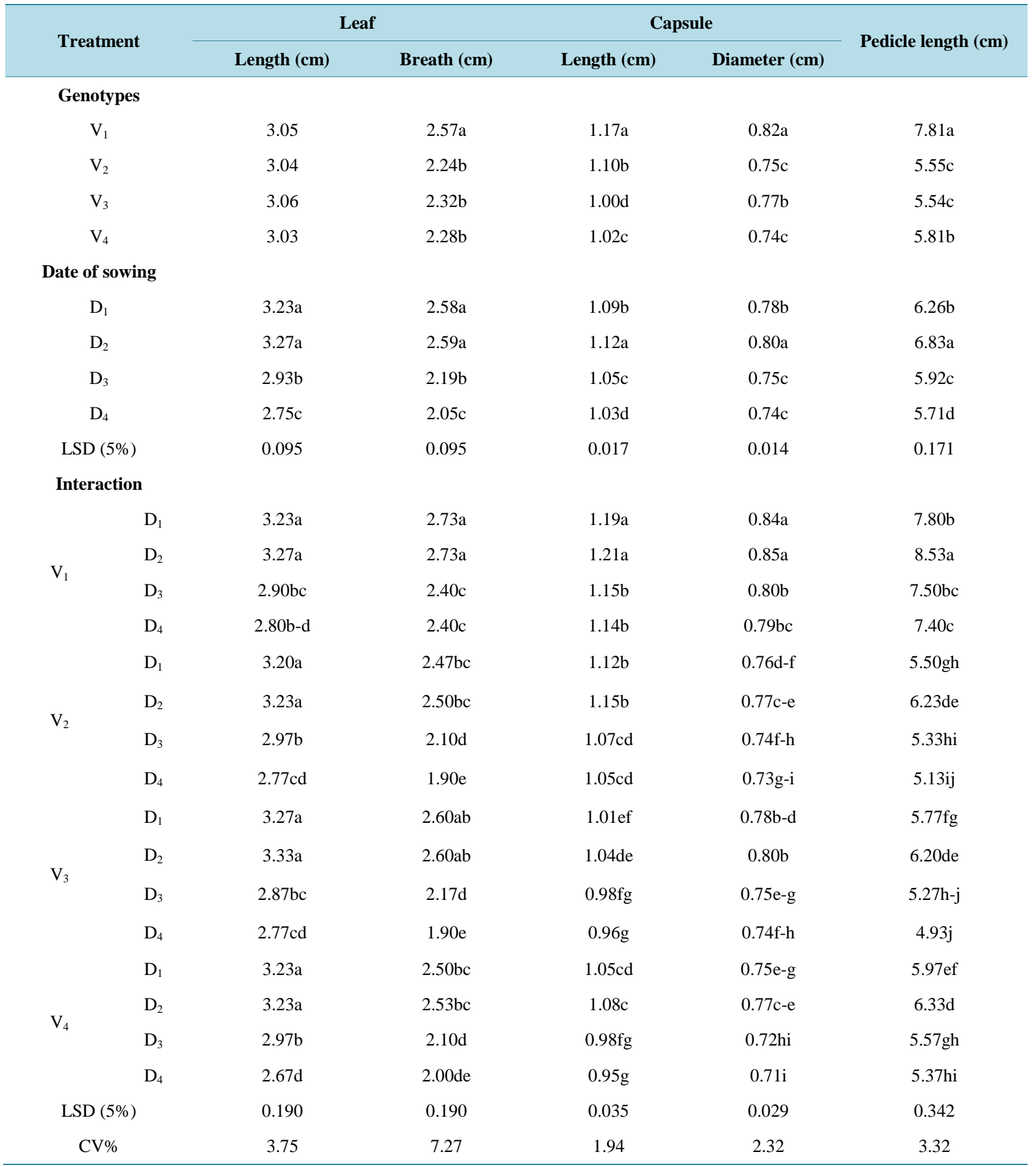

Means followed by the same letter(s) in a column are not significantly different. Variety: Exotic $\left(\mathrm{V}_{1}\right)$; BARI kalozira-1 ( $\left.\mathrm{V}_{2}\right)$; Faridpur local $\left(\mathrm{V}_{3}\right)$; Natore local $\left(\mathrm{V}_{4}\right)$. Date of sowing: 16 Oct, $2011\left(\mathrm{D}_{1}\right) ; 1$ Nov, $2011\left(\mathrm{D}_{2}\right) ; 16 \mathrm{Nov}, 2011\left(\mathrm{D}_{3}\right) ; 1$ Dec, $2011\left(\mathrm{D}_{4}\right)$.

\subsubsection{Breath of Leaf $(\mathrm{cm})$}

In breath of leaf, Genotype $V_{1}(2.57 \mathrm{~cm})$ was significantly different (Table 4) from $V_{2}(2.24 \mathrm{~cm}), V_{3}(2.32 \mathrm{~cm})$ and $\mathrm{V}_{4}(2.28 \mathrm{~cm})$. There was no significant different among $\mathrm{V}_{2}, \mathrm{~V}_{3}$ and $\mathrm{V}_{4}$. In case of date of sowing, $\mathrm{D}_{1}(2.58$ $\mathrm{cm})$ and $\mathrm{D}_{2}(2.59 \mathrm{~cm})$ was statistically similar, followed by $\mathrm{D}_{3}(2.19 \mathrm{~cm}) . \mathrm{D}_{4}(2.05 \mathrm{~cm})$ obtained the significantly the lowest leaf breath. In combined effect, the highest leaf breath $(2.73 \mathrm{~cm})$ was obtained from interaction of $\mathrm{V}_{1}$ with $\mathrm{D}_{1}$ and $\mathrm{D}_{2}$, and the lowest leaf breath $(2.00 \mathrm{~cm})$ was found in $\mathrm{V}_{4} \mathrm{D}_{4}$. 


\subsubsection{Length of Capsule $(\mathrm{cm})$}

Genotypes were significantly different from each other in capsule length (Table 4), where the highest obtained from $V_{1}(1.17 \mathrm{~cm})$, and the lowest $(1.00 \mathrm{~cm})$ from $V_{3}$. Second highest capsule, length was observed in $V_{2}(1.10$ $\mathrm{cm})$, followed by $\mathrm{V}_{4}(1.02 \mathrm{~cm})$. Date of sowing also effect significantly in capsule length, where maximum was in $\mathrm{D}_{2}(1.12 \mathrm{~cm})$, followed by $\mathrm{D}_{1}(1.09 \mathrm{~cm}) .1 .05$ and $1.03 \mathrm{~cm}$ capsule length were found in $\mathrm{D}_{3}$ and $\mathrm{D}_{4}$ simultaneously, which was statistically different. In interaction, $\mathrm{V}_{1} \mathrm{D}_{2}(1.21 \mathrm{~cm})$ gave the highest and $\mathrm{V}_{4} \mathrm{D}_{4}(0.95 \mathrm{~cm})$ gave the lowest capsule length.

\subsubsection{Capsule Diameter (cm)}

There was significant different among genotypes in capsule diameter (Table 4). It was maximum $(0.82 \mathrm{~cm})$ in $\mathrm{V}_{1}$, followed by $\mathrm{V}_{3}(0.77 \mathrm{~cm})$, which was statistically different. $\mathrm{V}_{2}(0.75 \mathrm{~cm})$ and $\mathrm{V}_{4}(0.74 \mathrm{~cm})$ showed no significant different. Capsule diameter also varied in various sowing date. $\mathrm{D}_{2}(0.80 \mathrm{~cm})$ showed the highest followed by $\mathrm{D}_{1}(0.78 \mathrm{~cm})$. No significant different was observed in $\mathrm{D}_{3}(0.75 \mathrm{~cm})$ and $\mathrm{D}_{4}(0.74 \mathrm{~cm})$. In combined effect of genotype and date of sowing, capsule diameter was highest $(0.85 \mathrm{~cm})$ in $\mathrm{V}_{1} \mathrm{D}_{2}$ and lowest $(0.71 \mathrm{~cm})$ in $\mathrm{V}_{4} \mathrm{D}_{4}$.

\subsubsection{Length of Pedicle (cm)}

Genotypes showed significant different in pedicle length (Table 4). Genotype $V_{1}(7.81 \mathrm{~cm})$ gave maximum pedicle length, where minimum was observed in $V_{3}(5.54 \mathrm{~cm})$. No significant different was found in $\mathrm{V}_{2}(5.55 \mathrm{~cm})$ and $\mathrm{V}_{3} . \mathrm{V}_{4}(5.81 \mathrm{~cm})$ showed moderate pedicle length. Pedicle length was also effected significantly by various date of sowing. $\mathrm{D}_{2}(6.83 \mathrm{~cm})$ showed maximum pedicle length, where $\mathrm{D}_{4}(5.71 \mathrm{~cm})$ showed the minimum. $\mathrm{D}_{1}$ $(6.26 \mathrm{~cm})$ and $\mathrm{D}_{3}(5.92 \mathrm{~cm})$ showed moderate pedicle length. Each date of sowing was significantly different from each other. In combined effect, $V_{1} D_{2}$ showed $(8.53 \mathrm{~cm})$ highest and $\mathrm{V}_{3} \mathrm{D}_{4}(4.93 \mathrm{~cm})$ showed the lowest pedicle length.

\subsubsection{Fresh Weight per Plant (g)}

It indicates plant size and vigor (Table 5). There was significant different among genotypes in fresh weight per plant (Table 5) which varied from 9.39g $\left(\mathrm{V}_{4}\right)$ to $13.87 \mathrm{~g}\left(\mathrm{~V}_{1}\right)$. $\mathrm{V}_{2}$ showed 10.11g and $\mathrm{V}_{3}$ 9.76g. Each genotype was significantly different from each other. Shah (2011), in India reported less fresh weight per plant $3.36 \pm$ $0.27 \mathrm{~g}$. Date of sowing was also effect on fresh weight per plant. $\mathrm{D}_{1}(12.95 \mathrm{~g})$ gave the highest and $\mathrm{D}_{4}(9.47 \mathrm{~g})$ the lowest. $\mathrm{D}_{2}$ and $\mathrm{D}_{3}$ gave moderate fresh weight per plant which was 10.83 and $9.88 \mathrm{~g}$. Each date of sowing was statistically different from one another. In interaction, maximum fresh weight was obtained from $V_{1} D_{1}$ (16.15 g) and minimum from $\mathrm{V}_{4} \mathrm{D}_{4}(8.40 \mathrm{~g})$.

\subsubsection{Number of Seeds per Capsule}

Different was found among genotypes in number of seed per capsule (Table 5). $\mathrm{V}_{1}$ (95.77) and $\mathrm{V}_{4}(95.51)$ showed higher and significantly similar number of seed per capsule. $\mathrm{V}_{2}(93.53)$ and $\mathrm{V}_{3}$ (89.58) were significantly similar. In date of sowing, $\mathrm{D}_{4}$ (98.24) was higher followed by $\mathrm{D}_{1}$ and $\mathrm{D}_{2}$ which each was $95.35 . \mathrm{D}_{3}(89.58)$ was significantly lower in number of seed per capsule. In combined effect of genotypes and date of sowing, maximum number of seed per capsule was obtained from $V_{1} D_{4}(100.67)$ and minimum from $V_{3} D_{3}$ (88.73).

\subsubsection{Number of Capsule per Plant}

Among yield contributing characters, number of capsule per plant is one of the most important. There was significant different among species in number of capsule per plant (Table 5), which was maximum 20.28 in $V_{1}$ and minimum 16.61 in $V_{4}$. $V_{2}$ (17.38) and $V_{3}(17.22)$ was statistically similar. On the other hand, date of sowing also effect on capsule per plant. It was maximum in $\mathrm{D}_{2}$ (22.06) followed by $\mathrm{D}_{1}$ (21.55), $\mathrm{D}_{3}(14.88)$ and $\mathrm{D}_{4}(12.99)$. In combined effect, the highest 24.17 was obtained from $V_{1} D_{2}$, and the lowest (12.17) from $V_{4} D_{4}$.

\subsubsection{Fresh Seed Weight per Capsule (g)}

There was no significant different among genotypes in fresh seed weight per capsule (Table 5). Maximum weight ( $0.21 \mathrm{~g}$ ) was obtained from $\mathrm{V}_{1} . \mathrm{V}_{2}, \mathrm{~V}_{3}$ and $\mathrm{V}_{4}$ gave same fresh seed weight which was $0.20 \mathrm{~g}$. But in case of sowing date $\mathrm{D}_{1}(0.21 \mathrm{~g}), \mathrm{D}_{2}(0.22 \mathrm{~g})$ and $\mathrm{D}_{3}(0.21 \mathrm{~g})$ was statistically similar and was different from $\mathrm{D}_{4}(0.17$ g). In interaction, maximum weight was $0.22 \mathrm{~g}$ which was found in $V_{1}$ combination with $D_{2}$ and $D_{3}$. Minimum 
Table 5. Plant weight and capsule characteristics contributing to yield in black cumin genotypes as influenced by sowing time.

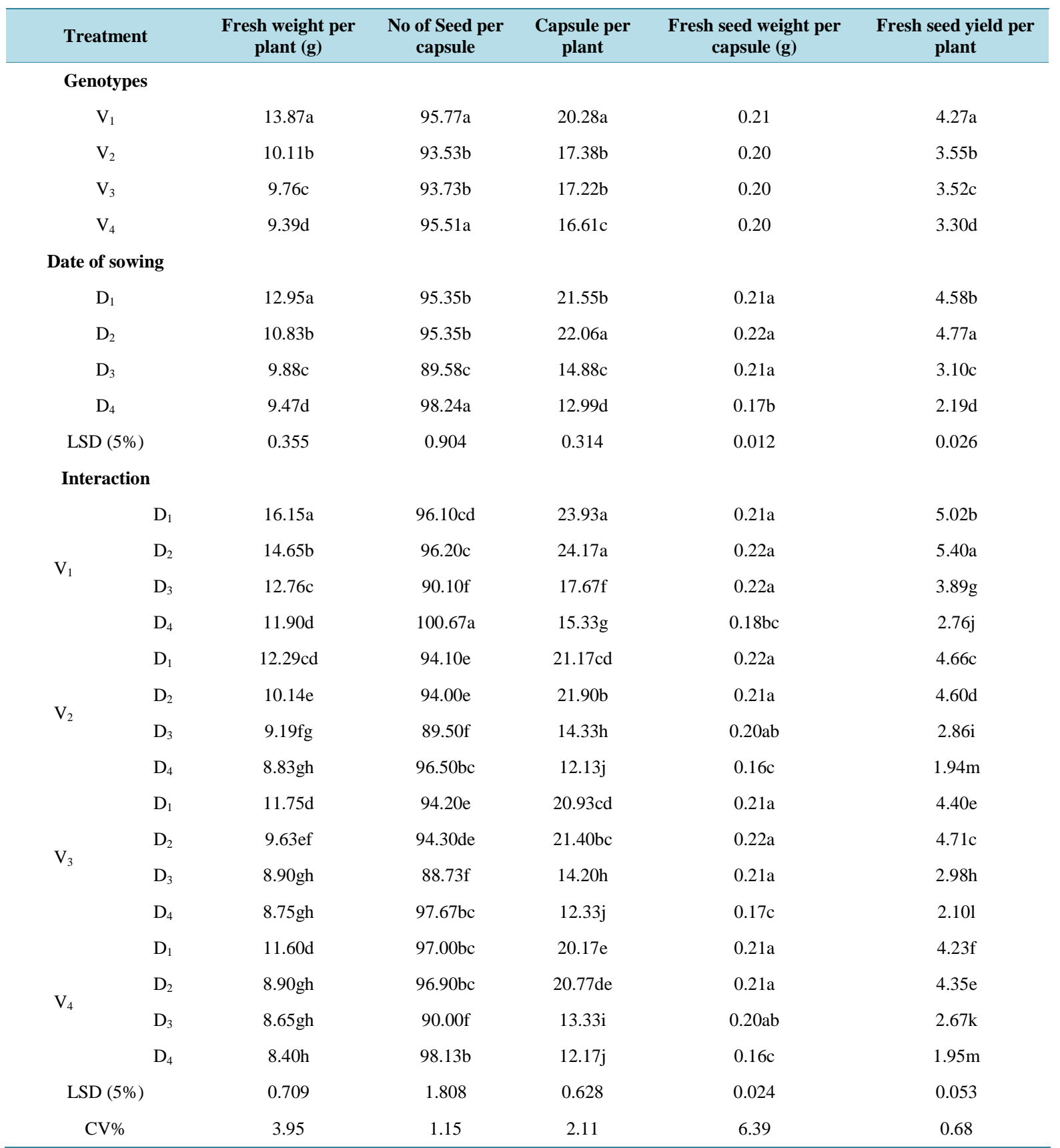

Means followed by the same letter(s) in a column are not significantly different. Variety: Exotic $\left(\mathrm{V}_{1}\right)$; BARI kalozira-1 ( $\left.\mathrm{V}_{2}\right)$; Faridpur local ( $\left.\mathrm{V}_{3}\right)$; Natore local $\left(\mathrm{V}_{4}\right)$. Date of sowing: 16 Oct, $2011\left(\mathrm{D}_{1}\right) ; 1$ Nov, $2011\left(\mathrm{D}_{2}\right) ; 16 \mathrm{Nov}, 2011\left(\mathrm{D}_{3}\right) ; 1$ Dec, $2011\left(\mathrm{D}_{4}\right)$.

0.16 g was obtained from $\mathrm{V}_{4} \mathrm{D}_{4}$.

\subsubsection{Fresh Seed Yield per Plant (g)}

Genotypes were statistically different from each other in fresh seed yield per plant (Table 5). Maximum yield was observed in $\mathrm{V}_{1}(4.27 \mathrm{~g})$ and minimum in $\mathrm{V}_{4}(3.30 \mathrm{~g})$. $\mathrm{V}_{2}$ and $\mathrm{V}_{3}$ were moderate as 3.55 and $3.52 \mathrm{~g}$ simultaneously. Date of sowing also effect significantly in fresh seed yield per plant. Maximum yield was obtained in $\mathrm{D}_{2}$ (4.77 g), followed by $\mathrm{D}_{1}(4.58 \mathrm{~g})$, which was statistically different. $\mathrm{D}_{3}(3.10 \mathrm{~g})$ was moderate and $\mathrm{D}_{4}(2.19 \mathrm{~g})$ 
was minimum which was statistically different. In interaction, maximum yield was obtained from $\mathrm{V}_{1} \mathrm{D}_{2}(5.40 \mathrm{~g})$ and minimum from $\mathrm{V}_{4} \mathrm{D}_{4}(1.95 \mathrm{~g})$.

\subsubsection{Dry Weight per Plant (g)}

There was significant different among all genotypes in dry weight per plant (Table 6). It was maximum in $V_{1}$ (9.01 g), and minimum in $\mathrm{V}_{4}(6.10 \mathrm{~g})$. $\mathrm{V}_{2}(6.58 \mathrm{~g})$ and $\mathrm{V}_{3}(6.34 \mathrm{~g})$ showed moderate dry weight per plant. Date of sowing was also significantly different from each other in dry weight per plant. $\mathrm{D}_{1}(8.42 \mathrm{~g})$ was maximum and $\mathrm{D}_{4}(6.16 \mathrm{~g})$ was minimum, where $\mathrm{D}_{2}(7.04 \mathrm{~g})$ and $\mathrm{D}_{3}(6.42 \mathrm{~g})$ were moderate. In combined effect, maximum dry weight per plant was observed in $\mathrm{V}_{1} \mathrm{D}_{1}(10.50 \mathrm{~g})$ and minimum $5.46 \mathrm{~g}$ in $\mathrm{V}_{4} \mathrm{D}_{4}$.

Table 6. Yielding characteristics in black cumin genotypes as influenced by sowing time.

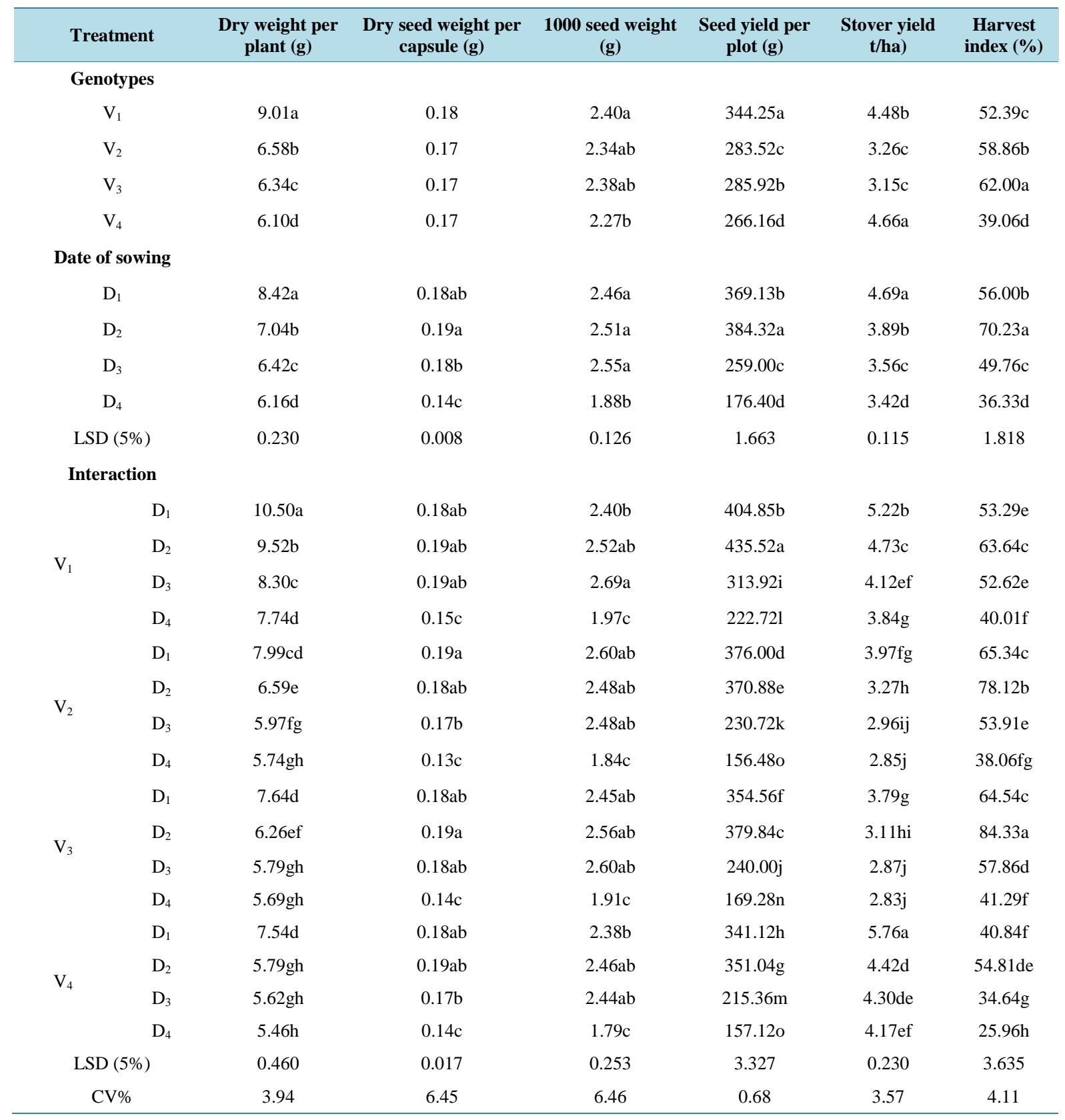

Means followed by the same letter(s) in a column are not significantly different. Variety: Exotic $\left(\mathrm{V}_{1}\right)$; BARI kalozira-1 ( $\left.\mathrm{V}_{2}\right)$; Faridpur local ( $\left.\mathrm{V}_{3}\right)$; Natore local $\left(\mathrm{V}_{4}\right)$. Date of sowing: 16 Oct, $2011\left(\mathrm{D}_{1}\right) ; 1$ Nov, $2011\left(\mathrm{D}_{2}\right) ; 16$ Nov, $2011\left(\mathrm{D}_{3}\right) ; 1$ Dec, $2011\left(\mathrm{D}_{4}\right)$. 


\subsubsection{Dry Seed Weight per Capsule (g)}

There was no significant different among genotypes in dry seed weight per capsule (Table 6). It was the highest in $V_{1}(0.18 \mathrm{~g})$, followed by $V_{2}, V_{3}$ and $V_{4}$ which each was $0.17 \mathrm{~g}$. Date of sowing significantly effect on dry seed weight per capsule. It was maximum in $\mathrm{D}_{2}(0.19 \mathrm{~g})$ which was statistically similar to $\mathrm{D}_{1}(0.18 \mathrm{~g})$. $\mathrm{D}_{1}$ also was statistically similar to $\mathrm{D}_{3}(0.18 \mathrm{~g})$, but different from $\mathrm{D}_{4}(0.14 \mathrm{~g})$. A variation was observed in interaction. Maximum dry weight was found in $\mathrm{V}_{2} \mathrm{D}_{1}(0.19 \mathrm{~g})$ and minimum $0.13 \mathrm{~g}$ in $\mathrm{V}_{2} \mathrm{D}_{4}$.

\subsubsection{Seed Weight (g)}

1000 seed weight is an important yield contributing character. It was maximum in $\mathrm{V}_{1}(2.40 \mathrm{~g})$ which was statistically similar to $V_{2}(2.34 \mathrm{~g})$ and $V_{3}(2.38 \mathrm{~g})$ (Table 6). $\mathrm{V}_{2}$ and $\mathrm{V}_{3}$ were also statistically similar to $\mathrm{V}_{4}(2.27 \mathrm{~g})$. In case of date of sowing, $\mathrm{D}_{1}(2.46 \mathrm{~g}), \mathrm{D}_{2}(2.51 \mathrm{~g})$ and $\mathrm{D}_{3}(2.55 \mathrm{~g})$ was statistically similar. $\mathrm{D}_{4}(1.88 \mathrm{~g})$ was statistically different from $\mathrm{D}_{1}, \mathrm{D}_{2}$ and $\mathrm{D}_{3}$. In combined effect of genotypes and date of sowing maximum 1000 seed weight $2.69 \mathrm{~g}$ was obtained from the interaction of $\mathrm{V}_{1}$ and $\mathrm{D}_{3}$, where minimum $1.79 \mathrm{~g}$ in $\mathrm{V}_{4} \mathrm{D}_{4}$.

\subsubsection{Dry Seed Yield per Plant (g)}

Yield of per plant contribute directly in total yield. Genotype each was significantly different from each other in dry seed yield per plant. Maximum yield was found in $V_{1}\left(3.59\right.$ g), followed by $V_{2}$ (2.98 g) (Figure $1(a)$ ). $V_{3}$ (2.95 g) showed moderate and $\mathrm{V}_{4}(2.77 \mathrm{~g})$ was minimum in yield per plant. In case of date of sowing (Figure $1(b))$, it was the highest in $\mathrm{D}_{2}(4.00 \mathrm{~g})$ which was statistically different from $\mathrm{D}_{1}(3.85 \mathrm{~g})$. Also $\mathrm{D}_{3}(2.60 \mathrm{~g})$ and minimum $\mathrm{D}_{4}(1.84 \mathrm{~g})$ was statistically different. In combined effect (Figure 2), maximum (4.54 g) yield was found in $\mathrm{V}_{1} \mathrm{D}_{2}$ and minimum $(1.64 \mathrm{~g})$ in $\mathrm{V}_{4} \mathrm{D}_{4}$.

\subsubsection{Stover Yield ( $\mathrm{t} / \mathrm{ha})$}

There was significant different among genotypes in stover yield (Table 6). Significantly maximum stover yield was found in $\mathrm{V}_{4}\left(4.66 \mathrm{t} / \mathrm{ha}\right.$ ) and minimum in $\mathrm{V}_{3}(3.15 \mathrm{t} / \mathrm{ha})$. $\mathrm{V}_{1}(4.48 \mathrm{t} / \mathrm{ha})$ and $\mathrm{V}_{2}(3.26 \mathrm{t} / \mathrm{ha})$ was statistically different, where $V_{2}$ and $V_{3}$ was statistically similar. On the other hand, date of sowing clearly effect on stover

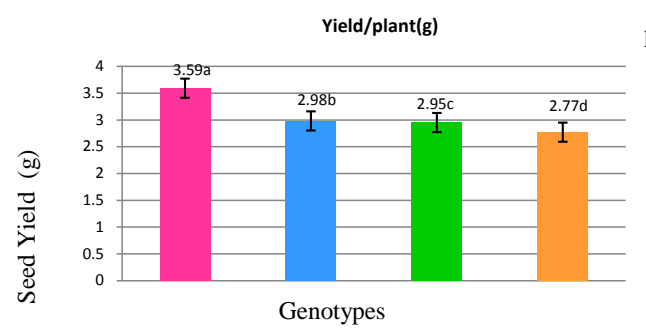

(a)

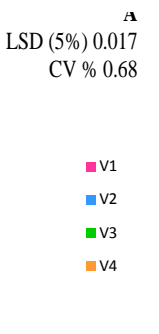

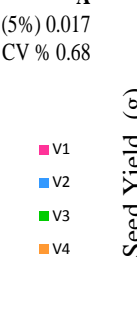$$
\text { क्षि}
$$

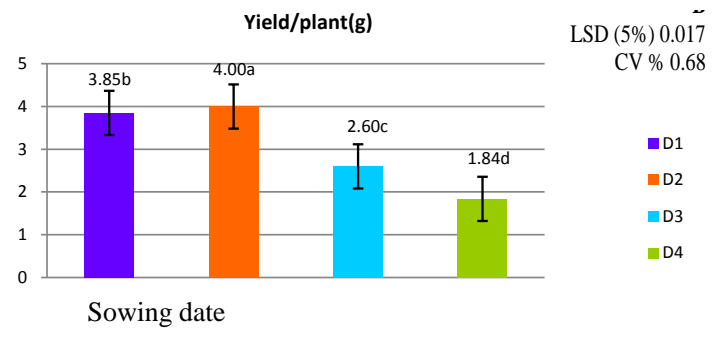

(b)

Figure 1. Seed yield per plant of black cumin as influenced by genotype (a) and date of sowing (b).

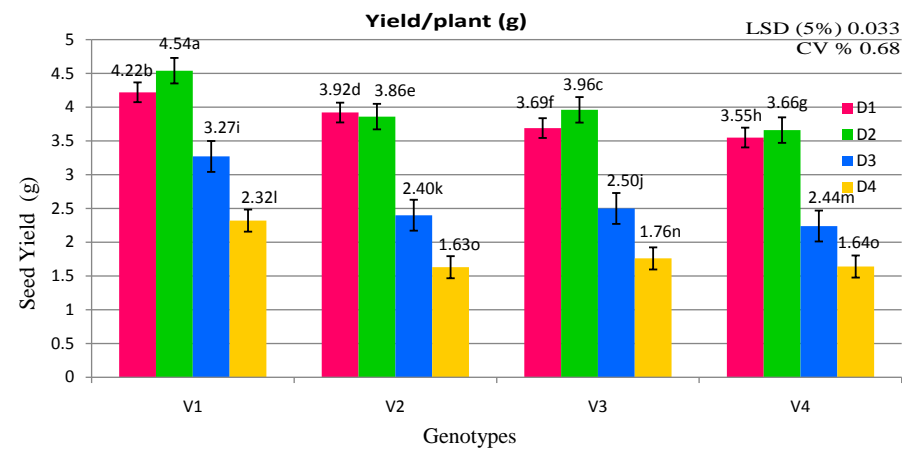

Figure 2. Seed yield per plant of black cumin as influenced by interaction of genotype and date of sowing. Vertical bars represent standard error of treatment means. Means followed by the same letter(s) in a column are not significantly different. Variety: Exotic $\left(\mathrm{V}_{1}\right)$; BARI kalozira-1 $\left(\mathrm{V}_{2}\right)$; Faridpur local $\left(\mathrm{V}_{3}\right)$; Natore local $\left(\mathrm{V}_{4}\right)$. Date of sowing: 16 Oct, $2011\left(\mathrm{D}_{1}\right)$; 1 Nov, $2011\left(\mathrm{D}_{2}\right) ; 16$ Nov, $2011\left(\mathrm{D}_{3}\right) ; 1$ Dec, $2011\left(\mathrm{D}_{4}\right)$. 
yield. Early sowing gave higher stover yield. It gradually decreased in late sowing. $\mathrm{D}_{1}(4.69 \mathrm{t} / \mathrm{ha}), \mathrm{D}_{2}$ (3.89 t/ha), $\mathrm{D}_{3}(3.56 \mathrm{t} / \mathrm{ha})$ and $\mathrm{D}_{4}(3.42 \mathrm{t} / \mathrm{ha})$ was statistically different from each other. In combination of genotype and date of sowing, the highest stover yield was obtained from $V_{4} D_{1}(5.76 t / h a)$, and the lowest ( $2.83 t /$ ha) from $V_{3} D_{4}$. In every genotype, gradually late sowing gave gradually lower stover yield.

\subsubsection{Harvest Index (\%)}

It is the indicator of efficient use of nutrients (Table 6). Each genotype was statistically different from each other in harvest index, where it was the highest in $\mathrm{V}_{3}(62.00 \%)$, and the lowest (39.06\%) in $\mathrm{V}_{4}$. $\mathrm{V}_{1}(52.39 \%)$ and $\mathrm{V}_{2}$ (58.86\%) showed moderate harvest index. Date of sowing also effect on harvest index. $\mathrm{D}_{2}$ (70.23\%) showed maximum harvest index, followed by $\mathrm{D}_{1}(56.00 \%)$. $\mathrm{D}_{3}(49.76 \%)$ showed moderate and $\mathrm{D}_{4}(36.33 \%)$ showed minimum harvest index. In interaction, $\mathrm{V}_{3} \mathrm{D}_{2}(84.33 \%)$ showed maximum and $\mathrm{V}_{4} \mathrm{D}_{4}(25.96 \%)$ showed the minimum.

\subsubsection{Seed Yield ( $\mathrm{t} / \mathrm{ha})$}

Seed yield per hectare is the ultimate goal. It was significantly the highest $2.37 \mathrm{t} / \mathrm{ha}$ in $\mathrm{V}_{1}$, followed by $\mathrm{V}_{2}(1.96$ $\mathrm{t} / \mathrm{ha}$ ) (Figure 3(a)). $\mathrm{V}_{2}$ and $\mathrm{V}_{3}\left(1.97 \mathrm{t} / \mathrm{ha}\right.$ ) were statistically similar. The lowest yield was found in $\mathrm{V}_{4}(1.84 \mathrm{t} / \mathrm{ha})$. In some places of Bangladesh, seed yield observed up to $1.5 \mathrm{t} / \mathrm{ha}$ (www.stoppressbd.com/news details/638). In case of date of sowing, it effect significantly in yield. Maximum yield was obtained from $\mathrm{D}_{2}(2.65 \mathrm{t} / \mathrm{ha})$, where minimum in $\mathrm{D}_{4}(1.22 \mathrm{t} / \mathrm{ha})$. $\mathrm{D}_{1}(2.55 \mathrm{t} / \mathrm{ha})$ and $\mathrm{D}_{3}(1.73 \mathrm{t} / \mathrm{ha})$ was statistically different (Figure 3(b)). In combined effect, maximum yield 3.00 t/ha was obtained in $\mathrm{V}_{1} \mathrm{D}_{2}$ and minimum $1.08 \mathrm{t} / \mathrm{ha}$ in $\mathrm{V}_{2} \mathrm{D}_{4}$ and $\mathrm{V}_{4} \mathrm{D}_{4}$ (Figure 4).

\subsubsection{Correlation among Characters}

Correlation co-efficient values and level of significance among 10 yields, yield attributing and other characters influenced by genotypes spacing are presented in Table 7. There was moderate and strong positive correlation

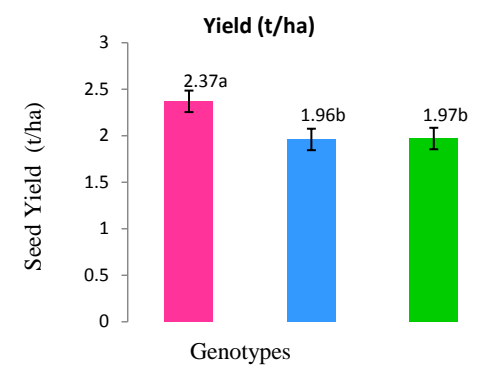

(a)
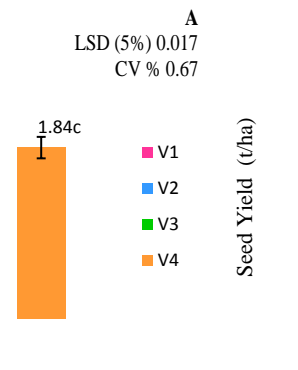

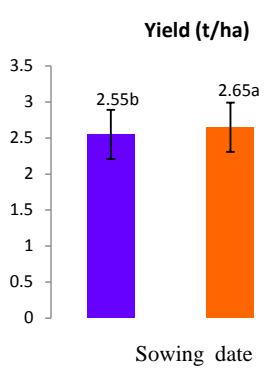

(b)

Figure 3. Seed yield ha ${ }^{-1}$ of black cumin as influenced by genotype (a) and date of sowing (b).

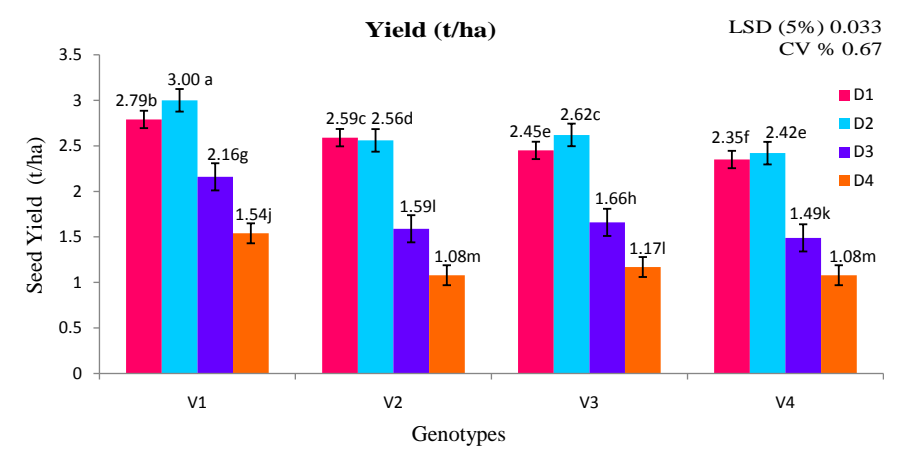

Figure 4. Seed yield ha ${ }^{-1}$ of black cumin as influenced by interaction of genotype and date of sowing. Vertical bars represent standard error of treatment means Means followed by the same letter(s) in a column are not significantly different. Variety: Exotic $\left(\mathrm{V}_{1}\right)$; BARI kalozira-1 $\left(\mathrm{V}_{2}\right)$; Faridpur local $\left(\mathrm{V}_{3}\right)$; Natore local $\left(\mathrm{V}_{4}\right)$. Date of sowing: 16 Oct, $2011\left(\mathrm{D}_{1}\right) ; 1$ Nov, 2011 $\left(D_{2}\right)$; 16 Nov, $2011\left(D_{3}\right) ; 1$ Dec, $2011\left(D_{4}\right)$. 
Table 7. Correlation coefficients among seed yield, yield determinants, plant height and number of branches in black cumin as influenced by genotypes and time of sowing.

\begin{tabular}{|c|c|c|c|c|c|c|c|c|c|c|}
\hline Characters & SY & $\mathrm{PH}$ & NPB & NSB & NTB & PL & SPC & СРР & TSW & STY \\
\hline $\mathrm{PH}$ & $0.82^{* *}$ & & & & & & & & & \\
\hline NPB & $0.57^{*}$ & 0.27 & & & & & & & & \\
\hline NSB & $0.90^{* *}$ & $0.75^{* *}$ & $0.67^{* *}$ & & & & & & & \\
\hline NTB & $0.87^{* *}$ & $0.89^{* *}$ & $0.58^{*}$ & $0.89^{* *}$ & & & & & & \\
\hline PL & $0.58^{*}$ & $0.87^{* *}$ & 0.30 & $0.53^{*}$ & $0.80^{* *}$ & & & & & \\
\hline SPC & 0.02 & 0.05 & 0.19 & 0.84 & 0.15 & 0.21 & & & & \\
\hline СРP & $0.97^{* *}$ & $0.83^{* *}$ & $0.63^{* *}$ & $0.96^{* *}$ & $0.93^{* *}$ & $0.63^{* *}$ & 0.10 & & & \\
\hline TSW & $0.67^{* *}$ & $0.51^{*}$ & 0.33 & $0.55^{*}$ & $0.53^{*}$ & 0.30 & $-0.67^{* *}$ & $0.61^{* *}$ & & \\
\hline STY & 0.43 & 0.31 & $0.80^{* *}$ & 0.49 & $0.57^{* *}$ & $0.54^{*}$ & 0.28 & $0.51^{*}$ & 0.18 & \\
\hline HI & $0.74^{* *}$ & $0.63^{* *}$ & 0.12 & $0.65^{* *}$ & $0.55^{*}$ & 0.23 & -0.28 & $0.70^{* *}$ & $0.69^{* *}$ & -0.21 \\
\hline
\end{tabular}

"Correlation is significant at the $5 \%$ level. ${ }^{* *}$ Correlation is significant at the $1 \%$ level, SY = Seed yield (t/ha); PH = Plant height $(\mathrm{cm})$; NPB = Number of primary branches per plant; NSB = Number of secondary branches per plant; NTB = Number of tertiary branches per plant; PL = Pedicle length $(\mathrm{cm}) ; \mathrm{SPC}=$ Seed per capsule; CPP = Capsule per plant; TSW = Thousand seed weight (g); STY = Stover yield (t/ha); HI = Harvest index (\%).

except seed per capsule. Relation with plant height at harvest $\left(0.82^{* *}\right)$, Number of primary branch per plant $\left(0.57^{*}\right)$, number of secondary branch per plant $\left(0.90^{* *}\right)$, number of tertiary branch per plant $\left(0.87^{* *}\right)$, pedicle length $\left(0.58^{*}\right)$, seed per capsule $(0.02)$, capsule per plant $\left(0.97^{* *}\right)$, 1000 seed weight $\left(0.67^{* *}\right)$, stover yield $(0.43)$ and harvest index $\left(0.74^{* *}\right)$. Plant height also had shown mostly positive strong and moderate correlation with character except seed per capsule (0.05). Number of primary, secondary and tertiary branch per plant showed strong positive correlation with almost characters but positive and week with seed per capsule. Pedicle length showed strong positive correlation with most characters but week seed per capsule (0.21), 1000 seed weight (0.30) and harvest index (0.23). Seed per capsule showed almost weak and sometime negative (1000 seed weight and harvest index). Capsule per plant exhibited mostly moderate positive correlation except seed per capsule. 1000 seed weight had moderate to week positive correlation with all characters. Stover yield (t/ha) exhibited moderate to week but positive correlation with all characters except harvest index $(-0.21)$. Harvest index showed moderate to week positive correlation with most character, except seed per capsule $(-0.28)$ and stover yield $(-0.21)$.

\subsection{Discussion}

The minimum period required to $1^{\text {st }}$ emergence may be due to high vigor of seed, and maximum period due to low vigor. Variation also observed in date of planting. Early sowing took significantly lower, and late sowing higher days, may be due to early sowing get upper temperature than late sowing which influenced $1^{\text {st }}$ emergence (Figure 5) and than late sowing which influenced 50\% emergence. Bud initiation, days to $1^{\text {st }}$ flower blooming and days to $50 \%$ flower blooming are influence by environment. Combination effect might be depended on genetical as well as environment. For flowering, a certain cool and humid weather was needed. Variation in days to $1^{\text {st }}$ capsule setting was observed in genotypes. Days to $50 \%$ capsule setting was statistically varied in genotypes. and gradually less time required from $\mathrm{D}_{1}$ to $\mathrm{D}_{4}$ with interaction with all genotypes. In days to first capsule ripening in early sowing, the highest days were obtained by $\mathrm{D}_{1}$, as well as lowest $\mathrm{D}_{4} \cdot \mathrm{D}_{2}$ and $\mathrm{D}_{3}$ take simultaneously. In combined effect, $\mathrm{V}_{1} \mathrm{D}_{1}$ took maximum time (134.33 days), where minimum (109.33 days) obtained from $V_{4} D_{4}$. The finding was nearly supported by [11] describing 135 to 145 days for ripening. It might be due to comparatively high temperature and humid weather. Plant height is an important factor. Genotypes were significantly different in plant height. This result of plant height was in partial conformity in case of $V_{2}$ with the findings of [11], where it was reported that height laid between 55 to $60 \mathrm{~cm}$. The result also partially similar to finding of Shah et al., (2006) [13] who found height 41.12 to $46.51 \mathrm{~cm}$. [14]) Valadabadi and Aliabadi (2011) found plant height 58 to $82 \mathrm{~cm}$ [15]. Tuncturk et al., (2005) found plant height 34.68 to $40.68 \mathrm{~cm}$. But [16] Toncer and 


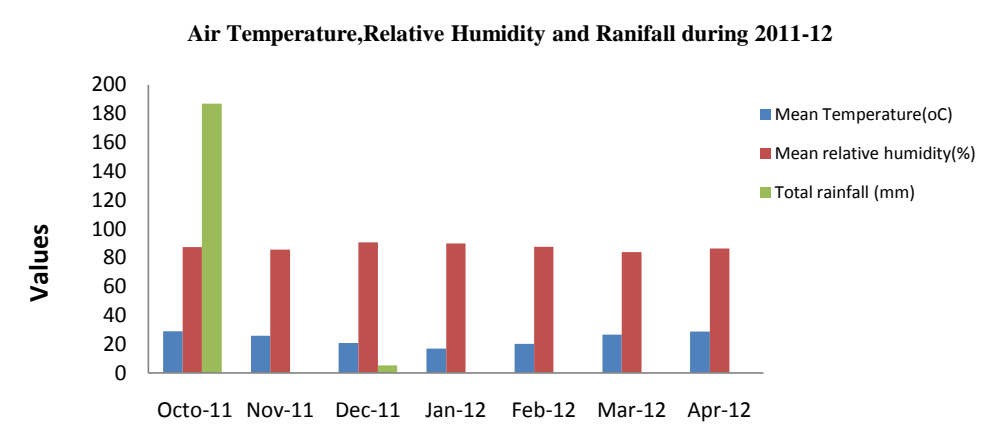

Months

Figure 5. Meteriological parameters of the experimental period (2011-12). Source: Weather Station, BSMRAU, Gazipur-1706.

Kizil (2004) found an upper range 64.9 to $71.5 \mathrm{~cm}$, and [17] Rahnavard et al., (2010) observed a lower range, up to $15.01 \mathrm{~cm}$. Plant heights might be controlled genetically, also environment could effect. Date of sowing was also significantly different from each other. Maximum height was found in $\mathrm{D}_{2}(50.78 \mathrm{~cm})$, and minimum $(44.15$ $\mathrm{cm}$ ) from $\mathrm{D}_{4}$. $\mathrm{D}_{1}$ and $\mathrm{D}_{3}$ showed 48.31 and $45.98 \mathrm{~cm}$ simultaneously. The result was supported by [18] Rasem et al., (2005) who reported that delay sowing significantly reduce the plant height. Primary branches per plant are an important yield contributing character. In case of $\mathrm{V}_{2}$, it was almost similar with finding of [11], where it was reported that number of primary branch was 5 to 7. Also [16] Toncer and Kizil (2004) reported number of branch 4.7 to 6.8 per plant, which was almost similar to finding [19]. Tuncturk et al., (2011) reported 3.76 branches per plant. It might be depended on genetical as well as environment. In case of number of secondary branch [20], Shah and Samiullah (2007) observed 7.2 to 11.74 branches per plant. Leaf area is the indicator of photosynthesis. Photosynthesis influences capsule setting, number of seed per capsule as a results production is increases. This result number of seed per capsule was in partial conformity with the findings of [16] Toncer and Kizil (2004) who reported that, number of seed per capsule varied from 90.7 to 92.8 . Also, in case of $V_{2}$, report from [11] BARI (2007) showed 75 to 80 seeds per capsule [15] Tuncturk et al., (2005) and [13] Shah et al., (2006) reported a few lower seed per capsule 66.45 to 71.72 and 52.01 to 52.17 respectively. It might be controlled genetically. In date of sowing, finding was supported by [17] Rahnavard et al., (2010) and [9] Sadeghi et al., (2009), who reported that, seed per capsule was higher in early sowing [18]. Rasem et al., (2005) found that delay sowing significantly reduced seed per capsule. Among yield contributing characters, number of capsule per plant is one of the most important. From this finding Slightly lower report were obtained from [21] Shah (2011) (16.45 \pm 1.2$), 15.12$ by [22] Shah (2007), 9.48 to 14.65 by [15] Tuncturk et al., (2005) and 15.26 to 16.50 by [13] Shah et al. (2006). But very few number of capsule per plant (4.68) was reported by [19] Tuncturk et al., (2011), and very higher (42.13) by [23] Sardooyi et al., (2011). It might be controlled genetically. On the other hand, date of sowing also effect on capsule per plant. Finding was supported by [17] Rahnavard et al., (2010) and [9] Sadeghi et al., (2009), who reported that, capsule per plant was higher in early sowing [18]. Rasem et al., (2005) found that delay sowing significantly reduced capsule per plant. Each was statistically different from each other. 1000 seed weight is an important yield contributing character. The result was similar to finding of [19] Tuncturk et al., (2011) who reported 1000 seed weight was $2.28 \mathrm{~g}$. Also the result was similar to [13] Shah et al., (2006) (2.45 to 2.50 g). In another experiment, [20] Shah and Samiullah (2007) described 1000 seed weight as 2.40 to $2.91 \mathrm{~g}$. The result also mostly supported by [15] Tuncturk et al., (2005), who described 1000 seed weight as 2.40 to $2.65 \mathrm{~g}$. A slightly low 1000 seed weight 1.79 to $1.89 \mathrm{~g}$ was found by [16] Toncer and Kizil (2004), and some higher as up to 5g, and up to 7g by [23] Sardooyi et al., (2011) and [11] BARI (2007) respectively. That might be due to genetic. In case of date of sowing, finding was supported by [17] Rahnavard et al., (2010), [9] Sadeghi et al., (2009), [18] Rasem et al., (2005) and [23] Sardooyi et al., (2011) who reported that, date of sowing had no significant effect or little on 1000 seed weight. Seed yield per hectare is the ultimate goal. The finding was supported by [24] Abdolrahimi et al., (2012), who observed seed yield up to 2.15 t/ha [20]. Shah and Samiullah (2007) described seed yield up to 1.55 t/ha. [14] Valabadi and Aliabadi (2011) found up to $1.43 \mathrm{t} / \mathrm{ha}$. In case of date of sowing, finding was supported by [17] Rahnavard et al., (2010), [9] Sadeghi et al. 
(2009) and [23]) Sardooyi et al., (2011) who reported that, early sowing gave higher yield. In case of stover yield, the finding was supported by [14] Valadabadi and Aliabadi (2011), who reported stover yield 3.49 to 4.23 t/ha. On the other hand, date of sowing clearly effect on stover yield. Finding was supported by [17] Rahnavard et al., (2010) and [9] Sadeghi et al., (2009) who reported that aboveground biomass was higher in early sowing. In every genotype, gradually late sowing gave gradually lower stover yield. Harvest index (\%) is the indicator of efficient use of each genotype was statistically different from each other in harvest index. The finding was similar to observation of [23] Sardooyi et al. (2011), who reported 51\% harvest index. [17] Rahnavard et al. (2010) also found 45\% harvest index. But the findings of [20] Shah and Samiullah (2007), [13] Shah et al. (2006) and [24] Abdolrahimi et al., (2012) were few lower as $30.30 \%$ to $32.91 \%, 30.01 \%$ to $30.21 \%$ and 23.93 to $25.84 \%$ respectively, might be due to genotypic character. In an experiment in Azerbaijan, [24] Abdolrahimi et al., (2012) found strong correlation of seed with stem weight $\left(0.99^{* *}\right)$, capsule weight $\left(0.99^{* *}\right)$, seed weight $\left(0.99^{* *}\right)$, 1000 seed weight $\left(-0.69^{* *}\right)$, which support current findings [17]. Rahnavard et al., (2010), in his experiment showed strong correlation $\left(\mathrm{r}=0.91^{* *}\right)$ between seed yield and aboveground biomass, but a negative one $(\mathrm{r}=$ $-0.68^{*}$ ) between aboveground biomass and harvest index, which strongly support current finding. Finding of [9] Sadeghi et al., (2009), in Iran was strong correlation $\left(\mathrm{r}=0.91^{* *}\right)$ between seed yield and above biomass, but a negative $\left(r=-0.68^{*}\right)$ with harvest index. Also these finding strongly support current findings. Correlation among various characters indicated that all these characters had significant contribution to seed yield and yield would be increased by improving these yield attributes.

\section{Conclusion}

The effect of planting time with genotypes was investigated to find out the suitable planting time in each genotype. The genotypes of black cumin showed variation in growth and yield behavior. Genotype $V_{1}$ (Exotic) was found suitable for higher seed production. Genotype $V_{4}$ (Natore local) was found as short durated and $V_{1}$ long durated crop. Seeds of $V_{1}$ (Exotic) and $V_{2}$ (BARI kalojeera1) showed higher germination and higher vigor sowing in 1 November followed by 16 October obtained the highest yield, and sowing in 16 October took maximum duration for harvest.

\section{References}

[1] Meena, S.S., Mehta, R.S., Meena, R.D., Meena, R.L. and Sharma, D.K. (2014) Economic Feasibility of Weed Management Practices in Nigella (Nigella sativa L.). Journal of Spices and Aromatic Crop, 23, 224-228.

[2] Nadeem, M.A., Tanveer, A., Naqqash, T., Jhala, A.J. and Mubeen, K. (2013) Determining Critical Weed Competition Periods for Black Seed. The Journal of Animal \& Plant Sciences, 23, 216-221.

[3] Rana, S., Singh, P.P., Naruka, I.S. and Rathore, S.S. (2012) Effect of Nitrogen and Phosphorus on Growth, Yield and Quality of Black Cumin (Nigella sativa L.). International Journal of Seed Spices, 2, 5-8.

[4] Sharangi, A.B. and Roychowdhury, A. (2014) Phenology and Yield of Coriander (Coriandrum sativum L.) at Different Sowing Dates. Journal of Plant Sciences, 9, 32-42. http://dx.doi.org/10.3923/jps.2014.32.42

[5] Moosavi, S.G., Seghatoleslami, M.J. and Moazeni, A. (2012) Effect of Planting Date and Plant Density on Morphological Traits, LAI and Forage Corn (Sc. 370) Yield in Second Cultivation. International Research Journal of Applied and Basic Sciences, 3, 57-63

[6] Kaleem, S., Hassan, F.U., Mahmood, I., Ahmad, M., Ullah, R. and Ahmad, M. (2011) Response of Sunflower to Environmental Disparity. Nature and Science, 9, 73-81.

[7] Moosavi, S.G. (2014) Fennel Morphological Traits and Yield as Affected by Sowing Date and Plant Density. Advance in Agriculture and Biology, 2, 45-49.

[8] Ehteramian, K. (2003) The Effects of Different Levels of Nitrogen Fertilizer and Plant Dating on Black Cumin (Cuminum carvi L.) in Kooshkak Region in the Fars Province. Master of Science Thesis of Arid Area Management, Shiraz University, Shiraz.

[9] Sadeghi, S., Rahnavard, A. and Ashrafi, Z.Y. (2009) Study Importance of Sowing Date and Plant Density Affect on Black Cumin (Cuminum carvi) Yield. Botany Research International, 2, 94-98.

[10] Saeidnejad, A.H., Kafi, M. and Pessarakli, M. (2012) Evaluation of Cardinal Temperatures and Germination Responses of Four Ecotypes of Bunium persicum under Different Thermal Conditions. International Journal of Agriculture and Crop Sciences, 4, 1266-1271.

[11] BARI (2007) Cultivation Method of BARI Kalozira-1. Leaflet of Spices Research Station, Publication No. Folder 
10/2007, Bangladesh Agricultural Research Institute, Sibganj, Bogra.

[12] Gomez, M.M. and Gomez, A.A. (1984) Statistical Procedures for Agriculture Research. 2nd Edition, John Wiley and Sons, New York, 640.

[13] Shah, S.H., Ahmed, I. and Samiullah (2006) Effect of Gibberellic Acid Spray on Growth, Nutrient Uptake and Yield Attributes during Various Growth Stages of Black Cumin (Nigella sativa L.). Asian Journal of Plant Sciences, 5, 881884. http://dx.doi.org/10.3923/ajps.2006.881.884

[14] Valadabadi, S.A. and Aliabadi, H.F. (2011) Investigation of Biofertilizers Influence on Quantity and Quality Characteristics in Nigella sativa L. Journal of Horticulture and Forestry, 3, 88-92.

[15] Tuncturk, M., Ekin, Z. and Turkozu, D. (2005) Response of Black Cumin (Nigella sativa L.) to Different Seed Rates Growth, Yield Components and Essential Oil Content. Journal of Agronomy, 4, 216-219. http://dx.doi.org/10.3923/ja.2005.216.219

[16] Toncer, O. and Kizil, S. (2004) Effect of Seed Rate on Agronomic and Technologies Characters of Nigella sativa L. International Journal of Agriculture and Biology, 6, 529-532.

[17] Rahnavard, A., Sadeghi, S. and Ashrafi, Z.Y. (2010) Study of Sowing Date and Plant Density Affect on Black Cumin (Cuminum curvi) Yield in Iran. Biological Diversity and Conservation, 3, 23-27.

[18] Rasem, G.H., Ndaf, M. and Sefidkan, F. (2005) Effect of Planting Date and Plant Density on Seed Yield and Yield Components of Anise. Journal of Research and Development, 75, 128-133.

[19] Tuncturk, M., Tuncturk, R. and Y1ldırım, B. (2011) The Effects of Varying Phosphorus Doses on Yield and Some Yield Components of Black Cumin (Nigella Sativa L.). Advances in Environmental Biology, 5, 371-374.

[20] Shah, S.H. and Samiullah (2007) Response of Black Cumin (Nigella sativa L.) to Applied Nitrogen with or without Gibberellic Acid Spray. World Journal of Agricultural Sciences, 3, 153-158.

[21] Shah, S.H. (2011) Gibberellic Acid Induced Amelioration of Salt Stress in Black Cumin (Nigella sativa L.). Genetics and Plant Physiology, 1, 65-78.

[22] Shah, S.H. (2007) Photosyntheic and Yield Responses of Nigella sativa L. to Pre-Sowing Seed Treatment with GA . $^{2}$ Turkish Journal of Biology, 31, 103-107.

[23] Sardooyi, A.M., Shirzadi, M.H. and Naghavi, H. (2011) Effect of Planting Date and Plant Density on Yield and Yield Components of Green Cumin (Cuminum cyminum L.). Middle-East Journal of Scientific Research, 9, 733-777.

[24] Abdolrahimi, B., Mehdikhani, P. and Tappe, A.H.G. (2012) The Effect of Harvest Index, Yield and Yield Components of Three Varieties of Black Seed (Nigella sativa) in Different Planting Densities. International Journal of Agricultural Sciences, 2, 93-101. 